\title{
THE EFFECT OF TEACHING LISTENING USING FOLKTALES ON STUDENTS' LISTENING ACHIEVEMENT (A Case of Regular Class of Eleventh Grade at MAN 1 Kendari)
}

\section{Rahmita Arga Mulya ${ }^{1}$ Nurnia $^{2}$ Siam $^{3}$}

rahmita.argamulya@gmail.com

${ }^{1}$ Halu Oleo University, Indonesia.

\begin{tabular}{l} 
ARTICLE INFO \\
\hline Keywords: \\
listening, folktales \\
How to cite: \\
DOI:
\end{tabular}

ABSTRACT
This study investigated the effect of using folktales on
students' listening achievement at the eleventh grade of
MAN 1 Kendari. This study applied a Pre-experimental
research design with one group pretest and posttest. The
population of this research was the eleventh- grade
students of senior high school in the academic year 2018
/2019. The sample of this research was all eleventh-grade
students of MAN I Kendari which consists of 30 students.
The Technique of sampling used by the researcher was
total sampling. The result showed there was a significant
effect of using folktales on students' listening achievement.
It was proven based on descriptive analysis, the mean
score of pretest was 48.4 and the posttest means score was
75.2 . Moreover, the result of hypothesis testing showed
that the mean value of pretest and posttest was 26.7 and
the standard deviation was 20.7 , while the standard error
means was 3.78 . The sig. (2-tailed) was 0.000 which smaller
than (<0.05), it can be concluded that H0 was rejected and
H1 was accepted which means there was an effect of using
Folktales in teaching Listening at Eleventh grade of MAN 1
Kendari.

\section{INTRODUCTION}

The use of authentic texts as teaching materials in communicative teaching opened the way for literature to be considered in language teaching. Since then literature has commonly been considered to be a way of having access to authentic materials although the ways and frequency of using literature have 
shown a great range of variety. Moody (1986:2) asserts that some people view literature as supplementary material for entertainment and motivation, some as central material because "literature is language".

There are many kinds of literature used in teaching English as a foreign language and one of them is folktales. Folktales might be useful for the teacher as a material in the teaching-learning process because students might be interested in learning English if used materials in their environment. Ruth (1984) describes a folktale as, "The prose narrative genre" of oral literature. The Folktale is a general term for the various kinds of narrative prose literature found in the oral traditions of the world. It is used for various related types of stories, which can include legends, myths, fables, parables, fairy tales, ghost stories, and many others. Therefore, in this research, the researcher wants to use folktale as a material in teaching listening that might be useful for the teacher to minimize students' boredom, makes the student become challenged to study it.

Nevertheless, studying English is never been easy as studying mother tongue. People who study English must acquire four skills, namely reading, listening, writing, and speaking. Listening and reading are receptive skills in which the students get an input of the language, while speaking and writing are productive skills in which the students produce the language as the result of the English learning process. Among those skills, listening is the essential one to be acquired. Listening is the basic skill in language learning because it is the first skill that developed in the very beginning of children learning of language. Buck (2001) says that a new language learner should learn to listen at the initial stage of language learning in the same manner as children learn a mother language. Another skill, speaking, writing, and reading will develop later when children mature.

In teaching listening, the teaching media that commonly used is tape or audio media which is called using traditional way. Schwartz (1998) notes that the greatest challenges of tape are integrating the listening experiences into 
classroom instruction and keeping up students' interest and motivation. Using folktales as media in teaching English helps sensitivity to students' sense of hearing. Folktales might explore a common theme in the lives of people, such as for example birth and childhood, challenge and adventure, love and marriage or death and inheritance. They sometimes also explain something about nature: why the seasons come and go, why animals look or act in a certain way. Aside from telling things about a certain country (social and cultural expression or behavior), friendship or love. Moral teaching also plays a significant role in many tales. Many students like literary work so much and it could make the students learning process easier because the tales are filled with hope, dreams, sorrow, and pain that they all share. They will be motivated and happy to learn English and using folktales can improve their listening comprehension.

Based on the observation result in the form of an interview with the teacher and students of MAN 1 Kendari when researcher went to observe teaching and learning process in the classroom, especially at the eleventh grade, the students' achievement in listening comprehension is low because the student's attention is low toward the topic. Over the years, the topics that turn by the teacher only spoken dialogue, so that students are less interested in listening to the contents of that dialogue.

In fact, the English teacher at MAN 1 Kendari was not focused on teaching listening to the eleventh grade. The teacher gave more focus to teach listening to the twelve grade that would face the national exam. In addition, the materials that were given to students during the listening class were not attractive and the teachers also have just a few experiences in teaching listening to the students at the eleventh grade. Therefore, to keep up students' interest and motivation toward listening class, the researcher interested to conduct research entitled "The Use of Folktales in Teaching Listening at MAN 1 Kendari" to figure out the essential use of Folktales as a material in teaching process in enhancing students' Listening achievement. 


\section{LITERATURE REVIEW}

\section{Insights of Listening}

In learning English there are four skills namely, listening, reading, speaking, and writing. Listening comprehension is one of the most important components in English as Foreign Language teaching and learning process and as oral speech communication. According to Gilman and Moody (1984), "about 40-50\% of communication time is spent by adults listening". Richard (2008: 2) says that the nature of listening can be simply understood with the traditional way to say it as listening comprehension. Based on that assumption, the main function of listening in second language learning is to facilitate the understanding of spoken discourse.

Listening is an essential part of the communication process. Students spend the majority of each school day listening and much of what students know is acquired through listening. Listening comprehension is a cognitive and interactive process of constructing meanings that the speaker intends, through the complete involvement of the hearer. According to Littlewood (2013), "the active contribution of the listener's comprehension process comes not only through using his linguistic knowledge but also his nonlinguistic sources, and of course, the communicative value of his involvement depends on the situation and the social relationship".

Listening in a foreign language is a complex task, which ranges from perception to comprehension and requires the interaction between top-down and bottom-up cognitive processes partly mediated by attention and memory mechanisms (Delvaux et al, 2015). Hedge (2000) in Cartwright (2014) explains that when listening to somebody or something we use different strategies in order to understand the message and that is why it is so important for teachers to help their students to learn how to listen. There are two main views of listening bottom-up process and a top-down listening process.

The Bottom-up process relate to the listeners' ability to distinguish sounds heard in speech and to reconstruct the speaker's message. Hedge (2000: 230) 
points out that "we use our knowledge of the language and our ability to process acoustic signals to make sense of the sounds that speech presents to us". In other words, we create the message from the individual parts e.g. from sounds to words to grammatical units to lexical meaning. And at the same time with this process, we use any clues that can help us with the meaning.

In addition, Flowerdew and Miller (2005: 24) define the bottom-up process as a model where the listeners build understanding by starting with the smallest units of the acoustic message: individual sounds, or phonemes. These are then combined into words, which, in turn, together make up phrases, clauses, and sentences. Finally, individual sentences combine to create ideas and concepts and relationships between them. Which means that the overall message is built up from phonetic units, which are placed together like building blocks and constructed into words, phrases, and sentences.

Top-down listening process is a process decoding of verbal messages depends more on listeners' prior knowledge of the world and/or the topic of the text than on knowledge of the language itself or its acoustic signals, Richard $(2008 ; 11)$. Whereas bottom-up processing goes from language to meaning, topdown processing goes from meaning to language. In short, the listener must put the language in the context of the situation to get the meaning. Native speakers usually use their background and cultural knowledge; and their previous knowledge for listening situations as they expect that certain situations are connected with typical features and language.

From the explanation above, listening comprehension is important to understand the spoken discourse and to improve oral speech communication. In learning a listening skill, Hedge had introduced two processes of listening namely bottom-up process and top-down process. Bottom-up processing goes from language to meaning, top-down processing goes from meaning to language. Moreover, when listening to somebody or something we use different strategies in order to understand the message and that is why it is so important for teachers to help their students to learn how to listen. 


\section{Comprehensive Listening}

As explained before, Worthington and Fitch-Hauser (2018) define comprehensive listening as the ability to perceive a speech and it is necessary for the listener to adopt an efficient principle for understanding the speech itself. Comprehensive listening involves understanding the message or messages that are being communicated. Like discriminative listening, comprehensive listening is fundamental to all listening sub-types. In order to be able to use comprehensive listening and gain understanding, the listener first needs appropriate vocabulary and language skills. Using overly complicated language or technical jargon, therefore, can be a barrier to comprehensive listening.

Rost (2011) defines comprehensive listening as listening to understand. Most of the public speeches will require a listener to utilize this type of listening and it is mostly used when listening to an Informative speech. In addition, Babace (2017) explains that comprehensive listening is further complicated by the fact that two different people listening to the same thing may understand the message in two different ways. This problem can be multiplied in a group setting, like a classroom or business meeting where numerous different meanings can be derived from what has been said.

Babace (2017) also explains that comprehensive listening is complimented by sub-messages from non-verbal communication, such as the tone of voice, gestures and body language. These non-verbal signals can greatly aid communication and comprehension but can also confuse and potentially lead to misunderstanding. In many listening situations, it is vital to seek clarification and use skills such as reflection aid comprehension.

\section{The Nature of Folktales}

There various material involved in English teaching and learning process, one of them is the use of literature as a useful material to trigger and motivated students to learn with enthusiasm and active. Folktales are one of the most used

literature material in teaching English. Nhung (2016) defines folktales as the Rahmita Arga Mulya: The Effect of Teaching Listening using Folktales on Students' Listening Achievement (A Case of Regular Class of Eleventh Grade at MAN 1 Kendari) 
most common types of folklore narrative which also means a story, myth or legend forming part of an oral tradition, does not have a single, identifiable author or writer and is or was passed down from one generation to the next.

Nhung (2016) also asserts that a folktale can change over time, be reshaped by modifications and was often changed with each retelling. Therefore, there is a possibility that one folktale can have various versions and chapters. Kennedy and Gioia (2007) also explain that folktales may be set in any time and any place and in this sense, they are almost timeless and placeless. Furthermore, a folktale especially the common type of tale follows conventions such as the formulaic beginning and ending, a setting not highly particularized in terms of time or place, flat and often stock characters, animal or human, and fairly simple plots.

\section{The Advantages of Using Folktales in Language Teaching}

Nhung (2016) suggests several advantages of use folktales as learning material in language teaching. The first is that folktales make learning fun, enjoyable and engaging to language learners, folktales provide meaningful, authentic comprehensible input which means that it shows an authentic situation of the real-life situation which can make learners can take a moral or life lesson from it. Folktales also provide opportunities for engaging learners in natural repetitions of new language, folktales allow learners to be exposed to various forms of discourse, it provides a good source of cultural information, accommodate a variety of engaging language activities and learning styles, encourage young learners' imagination and creativity, and folktales also help develop learners' perceptions of metaphoric language use.

Another advantage of using folktales in teaching and learning language also asserted by Oli (2016). He explains that folktales have many advantages to be used in the teaching and learning process. The advantages are; folktale is authentic, possible to enrich cultural and language ability, bring a desirable 
motivation of the learners, educate a reader to become a whole person and folktales also can make a learner fully involved in the learning process.

In conclusion, the folktales are useful learning literature to use in language teaching and learning process. It has many advantages and contribution to the learner. The learner can enjoy the learning process, creatively involved in a learning process with the authentic materials, and motivated them to comprehend both language and culture.

\section{RESEARCH METHODOLOGY}

In this study, the researcher used a Pre-experimental research design. One group will be given a pretest and posttest and will be given a treatment using Folktales as a learning material. This research included a pretest, that indicated students prior knowledge before treatment and a posttest indicated how participant measurement after treatment (Ary Donald,1979). This research is about figuring out the use of folktales in the process of teaching and learning listening.

The sample of this research was all eleventh grade students of MAN I Kendari class XI Regular class which consists of 30 students. The technique of sampling used by the researcher is total sampling. The sample in this study is taking on the consideration of students' experiences in learning listening which has not been treat using folktales as a learning material.

The instrument of this study is a listening test. The test consisted of 13 numbers. The topic is Dragon \& the princess. The questions divided into two parts, the first part consisted of 5 numbers with a true or false question and the second part consisted of 8 numbers multiple choice. Audio duration \pm 3 minutes. Students have time to answer all of the questions13 minutes. The audio will be played 3 times. The score that is used for each item 1 is for the right answer and 0 for the wrong answer. The function of the test used to know the student listening achievement by listening to audio that is provided by the researcher 
This study used listening tests in the form of multiple choice questions to know students' listening comprehension which given to students in pretest and posttest. Before conducting a pretest and posttest, the researcher previously conducts a pilot study to examine the reliability of the listening test used in this research. The pilot study conducted in a purpose to ensure that the instruments used in this study are suitable for use. Besides, according to Hazzi and Maldaon (2012), a pilot study also necessary to conduct because it lies in improving the quality and efficiency of the main study.

In conducting a pilot study, there are two kinds of analysis namely; validity and reliability analysis. The listening tests in the form of multiple choice questions were intended to be given to the sample of the study previously given to another sample which has similar background knowledge with the assigned sample. The researcher chose the eleventh grade of literature class to become a pilot class. After gathering the data about the test result, the researcher analyzes the data using spss 16 for windows

\section{FINDINGS AND DISCUSSION}

Listening comprehension is an interactive process involving active guessing, approximation, expectation, idealization which makes extensive use later in a typical speech. In this study, folktales were applied in listening teaching and learning process with the aim of improving students listening achievement. Here, the researcher will explain the findings of the quantitative data and explanation about the obtained result related to students' progress in listening class.

\section{Descriptive Analysis of Pre-test}

Related to the description of students pre-test score, it can be seen that the maximum score of the pre-test is 69.2 , the minimum score is 30.8 , deviation standards is 13.8, and the mean score is 48.4 . Based on the classification of listening criteria provided by Loekmono (1994) the interval score between 41-60 
is on enough criteria. The writer then classifies the students' scores for determining the level of students' listening achievement in terms of very high to very low as described in table 1.

Table 1. Distribution of Students' Score on Pre-Test

\begin{tabular}{|c|c|c|c|c|}
\hline No & Classification & Interval Score & Frequency & $\begin{array}{c}\text { Percentage } \\
\%\end{array}$ \\
\hline 1 & Very High & $81-100$ & 0 & 0 \\
\hline 2 & High & $61-80$ & 9 & 30 \\
\hline 3 & Enough & $41-60$ & 10 & 33.4 \\
\hline 4 & Low & $21-40$ & 11 & 36.6 \\
\hline 5 & Very Low & $0-20$ & 0 & 0 \\
\hline \multicolumn{2}{|c|}{ Total } & 30 & 100 \\
\hline
\end{tabular}

\section{Descriptive Analysis of Post Test}

This section discusses the descriptive statistical analysis of students' listening achievement after treatment in listening class. Students' listening achievement is measured after taking a pretest to find out students' prior ability in listening. Related to the description of students post-test score, it can be seen that the maximum score of the post-test is 100 , the minimum score is 38.5 , deviation standards is 18.1, and the mean score is 75.2. Based on the classification provided by loekmono (1994), the interval score 61-80 is on high criteria. So, the mean score of the pre-test 75,2 is categorized as high criteria. The writer then classifies the students' scores for determining the level of students' listening achievement in terms of very high, high, enough, low, and very low listening as described in table 2.

Table 2 Distribution of Students' Score on Post-Test

\begin{tabular}{|l|l|l|l|l|}
\hline No & Composition & Interval & Frequency & Percentage \\
\hline
\end{tabular}

Rahmita Arga Mulya: The Effect of Teaching Listening using Folktales on Students' Listening Achievement (A Case of Regular Class of Eleventh Grade at MAN 1 Kendari) 


\begin{tabular}{|c|c|c|c|c|}
\hline & Category & Score & & $\%$ \\
\hline 1 & Very High & $81-100$ & 14 & 46.6 \\
\hline 2 & High & $61-80$ & 12 & 40 \\
\hline 3 & Enough & $41-60$ & 2 & 6.7 \\
\hline 4 & Low & $21-40$ & 2 & 6.7 \\
\hline 5 & Very Low & $0-20$ & 0 & 0 \\
\hline \multicolumn{2}{|c|}{ Total } & 30 & 100 \\
\hline
\end{tabular}

The distribution shows that there is an improvement in the mean score of students' listening achievement before and after being taught using folktales. In the pre-test, the mean of students scores is 48.4 , while in the post-test the mean is 75,2 . The writer concludes that there is an improvement of students listening achievement from pre-test to posttest. Therefore, it is recommended to continue applying this teaching media in listening class.

The result of this statistical analysis to find the answer to the research question and to test the hypothesis. The data shows that the mean value of pretest and posttest is 26.7 and the standard deviation is 20.7, while the standard error means is 3.78. The sig. (2-tailed) is 0.000 which smaller than $(<0.05)$.

Therefore, based on the discussion above, it can be interpreted clearly that the use of folktales in listening class is significantly influenced students' listening achievement which was proved by the enhancement of students mean score on pretest to posttest and the hypothesis testing which also showed that $\mathrm{HO}$ is rejected and H1 is accepted which means that there is an effect on students' listening achievement at eleventh grade of MAN I Kendari after being taught using folktales as a teaching and learning media in listening class.

\section{CONCLUSION AND RECOMMENDATION}

This study investigates the use of folktales in Teaching Listening at the Eleventh Grade of MAN 1 Kendari. The main result of data analysis that has been presented in the previous chapter could be summarized that there is a significant effect of folktales to teach listening at the eleventh grade of MAN 1 
Kendari. It was proven based on the descriptive analysis in which students' mean score of post-test (75.2000) is higher than the mean score of pre-test (48.4667). The data shows that the mean value of pretest and posttest is 26.7 and the standard deviation is 20.7, while the standard error means is 3.78. The sig. (2tailed) is 0.000 which smaller than $(<0.05)$, it can be concluded that $\mathrm{H} 0$ is rejected and $\mathrm{H} 1$ is accepted which means that there is an effect of using Folktales in teaching Listening at Eleventh grade MAN 1 Kendari.

\section{REFERENCES}

Ahmadi, S. (2016). The Importance of Listening Comprehension in Language Learning. International Journal of Research in English Education, $1(1)$

Ary, Donald. (1979). Introduction to Research in Education. United State of America: Holt, Rinehart and Winston, Inc.

Babace, Hamidreza. (2017). A Comprehensive Look into the instruction of Listening Skill in Academic English Programs: A Case Study of two State Universities in Iran. International Journal of Education \& Literacy Studies. ISSN 2202-9478.Vol. 5 No. 2; April 2017

Buck,G.(2001). Assessing Listening.Cambridge: Cambridge University Press.

Cartwright, Leon. Townsend. (2014). Adapting Teaching to Improve Listening Instruction for a Business English Class in Japan. MA TEFL/TESL Module 1.

Celce-Murcia, M., \& Olshtain, E. (2000). Discourse and context in language teaching: A guide for language teachers. Ernst Klett Sprachen.

Chastain, K. (1998). Developing Second Language skills. 3 rd U.S.A: Harcourt Brace, Jovanovich, Inc.

Cohen, J. (1988). Statistical power analysis for the behavioral sciences (2nd ed.). Hillsdale, NJ: Erlbaum.

Delvaux, V. et all. (2015) Teaching listening in L2: A successful training method using the word spotting task.

Dujmovic, Mr.sc Mauro. Storytelling As A Method Of Efl Teaching. Visoka učiteljska škola, Pula. UDK: 371.3:811.111-26

Flowerdew, J \& Miller L (2005). Second language listening : Theory and Practice. Cambridge university press. 
Gilman, R.A. \& Moody, L.M. 1984 . What practitioners say about listening: Research implications or the classroom. Foreign Language Annals, $17,331-334$

Gough PB, Hoover WA, Peterson CL. Some observations on a simple view of reading. Reading Comprehension Difficulties: Processes and Intervention. 1996:1-13.

Hazzi, A. Osama \& Maldaon, Sh. Issa (2012) Prosocial Organizational Behaviors. European Journal of Economics, Finance and Administrative Sciences.

Hedge, T., 2000. Teaching and Learning in the Language Classroom. 1st ed. Oxford: Oxford University Press.

Kaspar, G. (1984). Pragmatic Comprehension in Learner - Native Speaker Discourse. Language Learning, 34, 1-20.

Kennedy, X. Y. and Gioia, D. (2007). Literature: an Introduction to Fiction, Poetry, Drama, and writing (10thed.). New York: Longman.

Littlewood, William (2013). Developing a Context-Sensitive Pedagogy for Communication-Oriented Language Teaching. English Teaching (Korea), September, 2013)

Loekmono, J. T (1994) . Belajar Bagaimana Belajar. Jakarta : PT.BPT Gunung Mulia

Lundsteen, S.W. (1979). Listening: Its Impact at All Levels on Reading and Other Language Arts. Illions: National Council of Teachers of English.

Lwin, S.M (2015). Using Folktales for Language Teaching. The English Teacher, XLIV(2), 74-83.

Maba, Wayan and Mantra Ida Bagus. (2017). Enhancing the Efl learners' speaking skill through folktales based instruction.

Moody H. L. B. (1986). Literary Appreciation. Longman: London.

Nhung, Pham Thi Hong. (2016). Folktales as a Valuable Rich Cultural and Linguistic Resource to Teach a Foreign Language to Young Learners. International Journal of Education, Culture and Society. 2016; 1(1): 23-28

Oduolowu, Esther and Oluwokemi, A.E. (2014). Effect of Storytelling on Listening Skills of Primary One Pupil in Ibadan North Local Government Area of Oyo State, Nigeria. International Journal of Humanities and Social Science. Vol. 4, No. 9; July 2014 
Oli, Alemitu. (2016). The Role of Folktales and Short Stories in Teaching Listening: The Case of Oromo Language. IJESC- International Journal of Engineering Science and Computing. Volume 6 Issue No. 11.

O’Malley, J., Chamot, A., \& Küpper, L. (1989). Listening Comprehension Strategies in Second Language Acquisition, Applied Linguistics, 10(4), 418-437.

Richards, Jack. C (2008). Teaching Speaking and Listening; from Theory to Practice. Cambridge University Press.

Rost. Michael. (2011). Teaching and Researching Listening. Second Edition. Longman, United Kingdom.

Ruth. F. (1984). Oral Literature in Africa. Nairobi: Oxford University press.

Schwartz, A. (1998). Listening in a Foreign Language: Washington, DC:Center for Applied Linguistics.

Tyagi, Babita. (2013), Listening : An Important Skill and Its Various Aspects. The Criterion An International Journal in English. ISSN 0976-8165

Wang, Hongyu. (2011). An Exploration on Designing College english Listening Class. Journal of Language Teaching and research. Vol. 2. No. 2. Pp. 359-363.

Worthington. Debra L. and Fitch-Hauser Margaret E. (2018). Listening Processes, Functions, and Competency.Second Edition, Taylor \& Francis. Routledge 711 Third Avenue, New York.

Zevenbergenn, A.A. \& Whitehurst, G.J. 2003. Dialogic reading: A shared picture book reading intervention for preschoolers. Reading books to children: parents and teachers. Eds. Kleek, V. Astahl, S. and. Bauer, E.B. Mahwah, JJ: Lawrence Erlbaum Associates. 177 - 200.

Ziane, Randa (2012). The Role of Listening Comprehension in Improving EFL Learners' Speaking Skill Case Study: Second Year Students (LMD) at Biskra University. A Desertation. 